\section{DETERMINE OF STOCK PRICE VOLATILITY ON MINING COMPANIES ON THE INDONESIA STOCK EXCHANGE}

\author{
Nurhasanah $^{1}$, Husaini $^{2}$, Arliansyah ${ }^{3}$, Johanda Syahputra $^{4}$ \\ ${ }^{1,2,3,4}$ Universitas Malikussaleh \\ Correspondence Address: Jl.Bukit Indah, 082275105510 \\ E-mail: husaini@unimal.ac.id
}

\begin{abstract}
The purpose of this study was to determine the effect of dividend policy, earning volatility, trading volume, exchange rates and interest rates on the volatility of stock prices in mining companies on the Indonesia Stock Exchange. The population studied in this study were all mining companies which were mining companies for the 2016-2019 period totaling 51. The sampling technique inthis study used a positive sampling method. The samples in this study were as many as 14 mining companies with the 2016-2019 observation year. The data analysis method used in this study is thepanel data regression analysis method. Dividend policy has a positive but insignificant effect on stock price volatility in mining companies on the Indonesia Stock Exchange. Profit volatility has a positive but insignificant effect on the volatility of share prices in mining companies on the Indonesia Stock Exchange. Trading volume has a positive and significant effect on the volatility of share prices in mining companies on the Indonesia Stock Exchange. Exchange rates have a positive and significant effect on stock price volatility in mining companies on the Indonesia Stock Exchange. Interest rates have a positive and significant effect on the volatility of share prices in mining companies on the Indonesia Stock Exchange.
\end{abstract}

Keyword: dividend policy, earning volatility, trading volume, exchange rates, interest rates, volatility of stock price

\section{INTRODUCTION}

Companies that go public adding funds in the development of their business can be obtained through the issuance of securities in the capital market (Ang, 2007: 324). The capital market is a meeting place for sellers and buyers of securities with the risk of profit and loss (Tandelilin, 2001: 13) Shares (stocks) are a letter of proof of ownership of the capital part of a company. Stock price is highly considered by investors because it is a standard measurement of the company's performance, so the issuer tries to maintain its achievements and constantly tries to improve its performance that can affect stock returns (Anggana, 2013). Investors in investing need available information such as the performance of the company, the risks faced by investors and factors that affect the price of the stock that will be used as consideration in determining the choice to buy the stock that is it is beneficial for him (Jogiyanto, 2008:98).

The company's funding policy also deals with the agency's theory that it is possible that management's interests conflict with those of shareholders, caused by managers putting their personal interests first. But contrary to the Pecking Order Theory where the agency's theory says that shareholders want the company's funding financed by debt, but not in accordance with the wishes of managers who assume that debt has a high risk to the development of the company. This difference in interests will lead to conflicts called agency problems (Tjeleni, 2013).

The state of rising or falling of the stock price in a certain period of time is also called stock price volatility. The volatility of a company's stock price is projected by an annual stock price range after adjustment of stock splits and dividend shares. Stock price volatility is a state in which the stock price deviates (upwards/ downwards) in the index from the average. What is meant here is the high level of volatility expressed in the rise and fall of a stock price chart. Of course, many factors can 
cause the rise or fall of the stock price itself, where in this study, the authors examined on variables that include dividend policy, earning volatility, trading volume, exchange rate and interest rates.

Investment opportunity setis the value of investment opportunities and is an option to make investments in the future. This investment opportunity set is related to the company's growth opportunities in the future. The company's growth is like an opportunity to invest in the future. The payment of dividends, especially cash dividends, is highly dependent on the available cash position.

Free cash flow owned by the company shows the cash available to investors. Free cash flow as cash available after all projects that generate a positive net present value (NPV) are carried out. Dividend payments reduce the free cash flow available for managers to invest. Companies with high cash flow rates should pay high dividends as well. Free cash flow is what often triggers the emergence of differences in interests between shareholders and managers.

When free cash flow is available, managers are allegedly going to waste the free cash flow so that inefficiency occurs in the company or will invest in free cash flow with a small return.(Sunarto \& Budi, 2010). The need for funds for the company is a factor that needs to be considered in determining the policy on dividends to be taken. In this study, the free cash flow as a proxy is free cash flow from operating activities and cash flow from funding (equity).

\section{THEORETICAL BASIS}

\section{Literature Review \\ 1.1 Dividen Policy}

Dividend policy is the decision of whether the profits earned by the company will be distributed to shareholders as dividends or will be held in the form of retained earnings for future investment financing. If the company chooses to distribute profits as dividends it will reduce retained profits and will further reduce the total source of internal funds (Sartono, 2001 in Setiawati, 2012). Retained earnings are one of the most important sources of funds to finance a company's growth, while dividends are cash outflows paid to shareholders. Dividends are the value of the company's net income after tax minus the retained earnings distributed to shareholders as a profit from the company's profits (Setiawati, 2012). Dividend payout ratio is a comparison between dividend per share (DPS) and Earnings Per Share (EPS).

\subsection{Earnings volatility}

Earnings volatility is a picture of how a company's earnings rise and fall in a period. In other words, earnings volatility is a picture of the level of stability of a company's income or profit. According to the signalling theory put forward by Jama'an (2008), the company should give a signal to the users of financial statements (creditors or investors). This signal is in the form of promotions or other information that states that the company is in good form.

Profit volatility is the degree of profit spread or index of the distribution of company's profit distribution (Wijayanti and Diyanti, 2016). In simple terms, profit volatility can be interpreted as a measure that indicates the level of fluctuation in profits obtained by a company from its operational activities in a given period. Profit volatility also indicates the level of risk, which is reflected in the magnitude of inequality over the high low profit earned by the company during a given period. The greater the inequality, the higher the volatility of profit, which means also the greater the risk that an entity has (Wijayanti and Diyanti, 2016). According to Dichev and Tang, (2006) greater profit volatility will decrease the quality of reported earnings. This is because profits that tend to fluctuate will make it difficult for users of financial statements to predict the company's future profits. Profit estimates can be biased and become inaccurate on fluctuating profit conditions. Stable profits are important for companies, as high profit volatility in one company can have a domino effect. According to Suwardjono, (2014) companies tend to feel anxious about fluctuations in profits that arise because it can cause investors to withdraw their investments in the company. The possibility of 
companies not distributing dividends due to fluctuations in their profits makes investors tend to avoid companies with high profit fluctuations.

\subsection{Volume trading activity}

Trading volume activity is the sale of every transaction that occurs on the stock exchange at a certain time and stock, and is one of the factors that also influences the movement of stock prices. Volume trading is a key element in predicting stock price movements. Trading volume is seen as an important piece of information that signals the next price movement where the stock price per can at least be conveyed to market participants (Mahajan and Singh, 2008).

Trading volume activity is the sale of every transaction that occurs on the stock exchange at a certain time and stock, and is one of the factors that also influences the movement of stock prices. Volume trading is a key element in predicting stock price movements. Trading volume is seen as an important piece of information that signals the next price movement where the stock price per se cannot be conveyed to market participants (Mahajan and Singh, 2008).

\subsection{Exchange rate}

According to Fabozzi and Franco, the amount of one currency that can be exchanged per unit of another currency, or the price of one currency in another currency (Fabozzi and Franco) The definition of an exchange rate according to Ekananda is the price of a country's currency relative to the currency of another country. Currency values play an important role in spending decisions, because they allow us to translate prices from different countries into the same language (Ekananda) The definition of exchange rate or exchange rate according to Salvator is the price of one currency against another.

The definition of exchange rate is also known as the exchange ratio between two different currencies of a country. In other words, the exchange rate can be interpreted as the price of one unit of foreign currency expressed in domestic currency. According to Mankiw foreign exchange or often called exchange rate (exchange rate) is the price level agreed upon by residents of both countries to trade each other. Exchange rates are often also referred to as forex, which is the exchange rate of a country's currency against the currency of another country.

\subsection{Interest Rates}

According to Sukirno (1994: 377), the payment of capital borrowed from other parties is called interest. Interest expressed as a percentage of capital is called interest rates. This means that the interest rate is the percentage of capital payments borrowed from the other party. According to Boediono (1985: 75) Interest rate is the price of the use of money for a certain period of time. Understanding the interest rate as this price can also be expressed as the price to be paid if there is an exchange between one rupiah now and one rupiah later.

So the interest rate is a percentage of the capital borrowed from outside parties or the level of profit earned by savers in the Bank or the level of fees incurred by investors who invest their funds in stocks. According to classical theory, interest is part of the use of funds available for loanable funds. This price occurs in the investment fund market, this occurs where in a certain period of time members of the public have excess income and then save excess income.

\subsection{Research Hypothesis}

Based on the theoretical framework that has been put forward, the hypothesis of this research is as follows:

$\mathrm{H} 1$ : There is a positive and significant influence of dividend policies on stock price volatility.

$\mathrm{H} 2$ : There is a positive and significant influence of earning volatility on stock price volatility.

H3: There is a positive and significant influence of trading volume on stock price volatility.

$\mathrm{H} 4$ : There is a positive and significant influence of the exchange rate on the volatility of stock prices.

$\mathrm{H} 5$ : There is a positive and significant influence of interest rates on stock price volatility. 


\section{IMPLEMENTATION METHOD}

This research is a study of the influence of Dividend Policy, Earning Volatility, Trading Volume, Exchange Rate and Interest Rates on Stock Price Volatility on Mining Companies on the Indonesia Stock Exchange Research Object is a mining company listed on the Indonesia Stock Exchange in 2016-2019, namely 45 companies consisting of 26 coal mining sector companies, 8 oil and gas mining company sector companies, 9 metal sector companies and Other minerals and 2 companies sector rocks.data obtained by looking directly for data on the closing price of monthly shares of companies listed on the IDX in 2016-2018 through the website www.yahoofinance.com the list of company names obtained from the website www.idx.co.id.

The population examined in this study is all mining companies that are mining companies from 2016 to 2019 amounting to 51 companies obtained from www.sahamok.com. The sampling technique in this study used porposive sampling methods. This research sample is a Mining Sector Company listed on the Indonesia Stock Exchange with the following criteria:

1. Mining companies listed on the Indonesia Stock Exchange (IDX) for the period 2016-2019.

2. Mining companies that contributed to profit during the period 2016-2019.

\section{RESULTS AND DISCUSSION}

\subsection{Descriptive Analysis of Statistics}

The stock price has an average value of 7.6176 with a standard deviation of 1.3819 , which is an average greater than the standard deviation which indicates that the Stock Price in this study is a small fluctuation value. The highest value of the stock price during the period 2016-2019 amounted to 11.2118 and the lowest value was 4.5325 . The number of observations made is 56 observations.

Descriptive results of statistics show that the average policy deviation is $0.1515(15.15 \%)$ with its standard deviation of $0.1318(13.18 \%)$ which is on average greater than the standard deviation which shows that the deviation policy in this study has small fluctuations. The highest value of the dividend policy is $0.1318(13.18 \%)$ and the lowest value is $0.0004(0.04 \%)$ while the number of observations made on the dividend policy is 56 observations.

Furthermore, profit volatility has an average of $0.1153(11.53 \%)$ with a standard deviation of $0.1067(10.67 \%)$ where the average value is above the standard deviation which indicates that fluctuations in profit volatility data in this study belong to small fluctuations. The highest value of profit volatility was $0.4047(40.47 \%)$ and the lowest value was $0.0005(0.05 \%)$ for 56 observations during the period 2016-2019.

Furthermore, the average trading volume in this study was $0.1423(14.23 \%)$ with a standard deviation of $0.1537(15.37 \%)$ which is lower on average than the standard deviation value which means fluctuations in trading volume data in this study are referred to in high fluctuations. The highest trading volume was $0.5391(50.91 \%)$ and the lowest was $-0.5343(-50.43 \%)$ in 56 observations during the period 2010-2017.

Furthermore, the average interest rate in this study was $0.0873(8.73 \%)$ with a standard deviation of $0.1277(12.77 \%)$ which is on average lower than the standard deviation value which means fluctuations in interest rate data in this study are referred to in high fluctuations. The highest interest rate was $0.0897(8.97 \%)$ and the lowest was $0.0423(4.23 \%)$ in 56 observations over the period 2016-2019.

Furthermore, the average rate in this study was $0.0751(7.51 \%)$ with a standard deviation of 0.0797 (7.97\%) which averaged lower than the standard deviation value which means fluctuations in exchange rate data in this study are referred to in high fluctuations. The highest rate was 0.5712 $(57.12 \%)$ and the lowest was $-0.0409(-4.09 \%)$ in 56 observations during the period 2016-2019.

\subsection{Panel Data Regression Model Selection Technique Chow Test}

Chow test is a test used to see models that match between common effect models or fixed effect models. If the chi square probability value is above the standard value of tolerance in this study 
which is 0.05 then the best model is the Common Effect Model (CEM) and if the probability value is above 0.05 then the best model is the Fixed Effect Model. The results of the Chow Test in this study are as follows:

Table 1.

\begin{tabular}{|l|l|l|}
\hline Model & Probability & Descripton \\
\hline Direct model & 0.0000 & Select FEM \\
\hline
\end{tabular}

Source: Processed Data, 2021

Based on the table above, it is seen that the direct model and interact model used in this study have a probability value on the Chow Test of 0.0000 where the value is in that error tolerance value, so the right regression model for direct is the fixed effect model and then the Hausman Test to determine the best model between FEM and REM. Hausman Test

\subsection{Hausman Test}

The Hausman test is a test to choose the best model between the fixed effect model and the random effect model. If the probability value on the Hausman Test is above the standard value o error tolerance which is 0.05 then the best model is the Random Effect Model, while if the probability value is below the standard value of error tolerance which is 0.05 then the best model is the Fixed Effect Model. The hausman test results in this study are as follows:

Table 2.

\begin{tabular}{|l|l|l|}
\hline Model & Probability & Descripton \\
\hline Direct model & 0.6390 & Select REM \\
\hline
\end{tabular}

Source: Processed Data, 2021

Based on the table above, it was found that the hausman test results for both models used in this study have a probability value of 0.6390 where the value is above the error tolerance value of 0.05 so that the correct data panel regression model is a random effect model and all classical assumption tests, regression estimates and testers A hypothesis will be done with a random effect model.

\subsection{Classic Assumption Test Normality Test}

The normality test conducted in this study was the Jarque Bera Test. In the Jarque Bera Test, the value seen is the probability value. A regression model is said to meet the assumption of normality if the probability value is greater than the standard value of error tolerance which is 0.05 . The results of the normality test as attached to Appendix 10 with the results presented in table 4.5 below:

Table 3.

\begin{tabular}{|l|c|c|c|}
\hline Model & J-Statistical & Probability & Observation Model \\
\hline Direct model & 0.687234 & 0,0000 & 96 \\
\hline
\end{tabular}

Source: Processed Data, 2021

Based on the table above, it was found that the probability value is good in the direct model of 0.0000 where the value is below the error tolerance value in this study so it can be concluded that the data in this study is distributed normally.

\subsection{Heteroskedasticity Test}


The heteroskedasticity test used in this study is the Harvey Test where the stage is to form the logarithm value of the residual square and regress all free variables to the logarithm value of the residual square (Widarjono, 2017). Harvey Test results in this study are presented in the table below:

\begin{tabular}{|l|c|c|}
\multicolumn{1}{|c|}{ Tabel 4 } \\
\begin{tabular}{|l|c|c|}
\hline \multicolumn{1}{|c|}{ Direct Effect } & \\
\hline C & & Prob \\
\hline Dividend Policy & 0.4922 & 0.5132 \\
\hline Volatility in Profit & 0.5964 & 0.5379 \\
\hline Trading Volume & 0.1148 & 0.7866 \\
\hline Exchange rate & 0.1577 & 0.8655 \\
\hline Interest Rates & 0,1732 & 0,8098 \\
\hline
\end{tabular}
\end{tabular}

Source: Processed Data, 2021

Based on the table above, it is seen that the entire probability value for free variables is above 0.05 so it can be concluded that the model used in this study is free from symptoms of heteroskedastisity.

\subsection{Multicollinearity Test}

The multicollinearity test in this study was conducted by looking at the correlation values between free variables in Table 4.2 of the Correlation Test Results. It is seen that all cells between free variables in this study have a correlation value below that of below 0.8 . Therefore, it can be concluded that there are no symptoms of multicolenearity in this study, meaning that between all the free variables in this study does not have a high correlation.

\subsection{Autocorrelation Test}

The autocorrelation test can be seen from the Durbin Watson value, for direct mdel has a Durbin Watson value of 0.9363 so it can be concluded that there are no symptoms of autocorrelation (Widarjono, 2017).

\subsection{Panel Data Regression Estimation}

Based on the results of the model selection test, the best panel data regression model in this study is the Random Effect Model (REM). Random Effect Model (REM) takes into account errors from panel data with the Least Square method. This model approach improves the efficiency of the least square process by taking into account errors from cross-sections and time series.

This model adds dummy variables to the panel data to allow for intercept changes (Gujarati and Porter, 2009). The results of regression of panel data in a Random Effect Model can be. 


\section{ORFAI JOURNAL Multidiciplinary Output Research For Actual and International Issue}

\begin{tabular}{|l|c|c|c|}
\hline & & \multicolumn{2}{|c|}{ Direct Effect } \\
\hline \multicolumn{1}{|c|}{ Coefficie nt } & Prob & \multicolumn{1}{|c|}{$\mathrm{t}$-countcoefficient } \\
\hline C & 7.0024 & & $14.771 * * *$ \\
\hline Dividend Policy & 0.2471 & & 0.2289 \\
\hline Volatility in Profit & 01.765 & & 0.5100 \\
\hline Trading Volume & 3.2291 & & $3.2069 * * *$ \\
\hline Exchange rate & 0.0087 & & $2.6033^{* * *}$ \\
\hline Interest Rates & & & $2.6547 * * *$ \\
\hline Adj $R$ Square & & 0.1073 & \\
\hline F-Statistic & & $3.8554 * *$ & \\
\hline Durbin Watson & & 0.9363 & \\
\hline
\end{tabular}

Source: Processed Data, 2021

The equations that can be built on the results of the regression random effect model above are as follows: Direct Model Equation:

Stock Price Volatility $=7.0024+0.2471+0.7248+1.7650+3.2291+3.2134$

\section{DISCUSSION}

\section{Effect of Dividend Policy on Stock Price Volatility}

Based on the test results in table 4.7 showed that the dividend policy had a positive and insignificant effect on stock price volatility with a koophysien value of 7.0024 and thitung of 0.8194 smaller than the ttabel of 1.986 so it can be concluded that the results of the study reject the H1 hypothesis which means the dividend policy has an effect on the ositive and insignificant to stock price volatility. The results of this study are in line with the findings of Rowena (2017) and Santioso (2019) who found that dividend policies have a positive and insignificant effect on stock price volatility, while the results of this study contradict the findings of Erbatiet al. (2013) which found that dividend policies have a significant effect on stock price volatility.

The value of a positive dividend policy coefficient means that the dividend policy can increase the stock price of the results of this research in accordance with the teory agency which means that increased investment can increase the stock price.

\section{Effect of Earning Volatility on Stock Price Volatility}

Based on the test results in table 4.7 showed that the volatility of earnings had a positive and insignificant effect on the volatility of stock prices with a koophysien value of 7.0024 and thitung of 0.5100 smaller than the ttabel of 1.986 so it can be concluded that the results of the study reject the $\mathrm{H} 2$ hypothesis which means that profit volatility is less than the standard of 1.986 so it can be concluded that the results of the study reject the $\mathrm{H} 2$ hypothesis which means that profit volatility is less. positive and insignificant effect on stock price volatility. The results of this study are in line with the findings of Han (2007), and Qie (2017) who found that profit volatility has a positive and significant effect on stock price volatility, while the results of this study contradict the findings of Erbatiet al (2013) which found that profit volatility had no significant effect on stock price volatility. volatility in stock prices. 
The value of the positive coefficient of profit volatility means that profit volatility can increase the stock price of the results of this study in accordance with the pecking teory which means that increased investment can increase the volatility of stock prices.

\section{Effect of Trading Volume on Stock Price Volatility}

Based on the test results in table 4.7 showed that trading volume has a positive and significant effect on the volatility of stock prices with a koophysien value of 7.0024 and thitung of 3.2069 greater than the ttabel of 1.986 so it can be concluded that the results of this study accept the H3 hypothesis which means trading volume is influential. positive and significant to the volatility of stock prices. The results of this study are in line with the findings of Ni Made Ayu Krisna Dewi and I Gst Ngr Agung Suaryana (2016) which found that Trading Volume has a positive and significant effect on stock price volatility, while the results of this study contradict the findings of Erbatiet al. (2013) Who found that Trading Volume had no significant effect on stock price volatility.

A positive Trading Volume coefficient value means that Trading Volume can increase the stock price of the results of this research in accordance with theory agency which means that increasing trading volume can increase the voilatility of stock prices.

\section{Effect of Exchange Rates on Stock Price Volatility}

Based on the test results in table 4.7 showed that the Exchange Rate had a positive and significant effect on the volatility of the stock price with a koophysien value of 7.0024 and thitung of 2.6033 greater than the ttabel of 1.986 so it can be concluded that the results of this study received the $\mathrm{H} 4$ hypothesis which means the Exchange Rate has a positive effect and significant to stock price volatility. The results of this study are in line with the findings of Han (2007) and Qie (2017) who found that exchange rates have a positive and significant effect on stock price volatility. Meanwhile, the results of this study contradict the findings of Erbatiet al. (2013) which found that the Exchange Rate had no significant effect on the volatility of the Stock Price.

A positive exchange rate coefficient value means that the exchange rate can increase the stock price of the results of this study in accordance with the Signal Theory which means that increasing the exchange rate can increase the volatility of the stock price.

\section{Effect of Interest Rates on Stock Price Volatility}

Based on the test results in table 4.7 showed that interest rates have a positive and significant effect on the volatility of stock prices with a koophysien value of 7.0024 and thitung of 2.6547 greater than the ttabel of 1.986 so it can be concluded that the results of this study Accept the H5 hypothesis which means interest rates have a positive and significant effect on stock price volatility. The results of this study are in line with the findings of Ni Made Ayu Krisna Dewi and I Gst Ngr Agung Suaryana (2016) which found that interest rates have a positive and significant effect on stock price volatility, while the results of this study contradict the findings of Erbatiet al. (2013). It found that interest rates had no significant effect on the volatility of stock prices.

The value of a positive Interest Rate coefficient means that interest rates can increase the stock price of the results of this study in accordance with the Signal Theory which means that rising interest rates can increase stock price volatility

\section{CONCLUSION}

1. The dividend policy has a positive but insignificant effect on the volatility of stock prices on mining companies on the Indonesia Stock Exchange.

2. Earnings volatility has a positive but insignificant effect on the volatility of stock prices on mining companies on the Indonesia Stock Exchange. 
3. Trading Volume has a positive and significant effect on the volatility of stock prices on Mining Companies on the Indonesia Stock Exchange.

4. The exchange rate has a positive and significant effect on the volatility of stock prices on mining companies on the Indonesia Stock Exchange.

Interest rates have a positive and significant effect on the volatility of stock prices on mining companies on the Indonesia Stock Exchange.

\section{Acknowledgments}

An infinite thank you to my colleagues, who have given a lot of feedback and advice on this research. Personal acknowledgements will be limited to appropriate professionals who contributed to this paper, including technical assistance and/or financial material support.

\section{REFERENCES}

Agung, J. S. (2015). Konsep dan Pengukuran Investment Opportunity Set pengaruhnya pada proses kontrak". Jurnal Akuntansi dan Manajemen. Jurnal Akuntansi dan Manajemen, 16(2), 141152.

Anugrah, A. D. P. (2014). Analisis Pengaruh Investment Opportunity Set (IOS) Terhadap Return Saham Perusahaan Sektor Manufaktur. Journal of Business and Management, 7(2), 94-100.

Brigham, \& Houston. (2016). Dasar-Dasar Manajemen Keuangan (Edisi 11.). Jakarta: Salemba Empat.

Daud, R. M. (2017). Pengaruh Operating Profit Margin, Dividend Payout Ratio, Profitabilitas, Dan Price Earning Ratio Terhadap Praktik Perataan Laba Pada Perusahaan LQ-45 Yang Terdaftar Di Bursa Efek Indonesia Tahun 2010-2014. Jurnal Akuntansi Muhammadiyah-JAM, 8(1), 110 .

Djarwanto. (2014). Pokok-pokokAnalisis Laporan Keuangan. Yogyakarta: BPFE.

Fahmi, I. (2014). Analisa Kinerja Keuangan. Bandung: Alfabeta.

Gudono, M. (2017). Hubungan Tindakan Perataan Laba dengan Reaksi Pasar atas Pengumuman Informasi Laba Perusahaan yang Terdaftar Di Bursa Efek Jakarta. Jurnal Ventura, 10(2), 114.

Gumanti, T. A. (2013). Kebijakan Deviden Teori,Empiris, dan Implikasi. Jakarta: UPP STIM YKPN.

Gumantri, T. A. (2013). Kebijakan Dividen Teori, Empiris, dan Implikasi. Jakarta: UPP STIM YKPN.

Halim, A. (2014). Manajemen Keuangan Sektor Publik,Problematika Penerimaan Dan Pengeluaran Pemerintah (Anggaran Pendapatan dan Belanja Negara/Daerah). Jakarta: Salemba Empat.

Harahap, S. S. (2013). Analisis Kritis Atas Laporan Keuangan. Jakarta: Rajawali Pers.

Harjito, A., \& Martono. (2013). Manajemen Keuangan (2nd ed.). Yogyakarta: Ekonisia.

Harmono. (2015). Manajemen Keuangan Bebasis Balenced Scorecard Pendekatan Teori, Kasus, dan Riset Bisnis. Jakarta: Bumi Angkasa.

Harnanto. (2013). Akuntansi Keuangan Menengah, Edisi 2003/2004,. Yogyakarta: BPFE.

Hartono. (2011). Teori Portofolio dan Analisis Investasi. Edisi. Kesepuluh. Yogyakarta: Andi.

Hasnawati, S. (2015). Dampak Set Peluang Investasi Terhadap Nilai Perusahaan Publik di Bursa Efek Jakart. JAAI, 9(2), 117-126.

Horne, J. C. Van, \& Wachowicz, J. M. (2012). Prinsip-prinsip Manajemen Keuangan (13th ed.). Jakarta: Salemba Empat.

IAI. (2009). Pernyataan Standar Keuangan 01 : Penyajian. Laporan Keuangan (Revisi 2009). Jakarta: IAI.

Jensen, M. C. (2011). Theory of the firm: Managerial behavior, agency cost and ownership structure. Journal of Finance Economic, 3(1), 305-360. 
Juliandi, A., Irfan, I., \& Manurung, S. (2015). Metode Penelitian Bisnis. Medan: UMSU Press.

Kadir, A., \& Phang, S. (2012). Analisis Faktor-Faktor yang Mempengaruhi Net Profit Margin Perusahaan Manufaktur yang Terdaftar pada Bursa Efek Indonesia, 13(1), 1-16.

Kallapur, S. dan T. (2016). The Invesment Opportunity Set: Determinant, Consequences and Measurement. Manajerial Finance (pp. 3-15).

Lucyanda, J. (2015). Pengaruh Free Cash Flow Dan Struktur Kempemilikan Terhadap Dividend Payout Ratio. Jurnal Dinamika Akuntansi, 4(2), 129-138.

Midiastuty. (2013). Analisis Hubungan Mekanisme Corporate Governance dan Indikasi Manajemen Laba. Artikel Simposium Nasional Akuntansi (SNA) VI, Surabaya (pp. 27-32).

Munawir, S. (2014). Analisis Laporan Keuangan. Yogyakarta: Liberty.

Murhadi, W. R. (2013). Analisis Laporan Keuangan Proyeksi dan Valuasi saham. Jakarta: Salemba Empat.

Norpratiwi, M. V. (2017). Analisis Korelasi Investment Opportunity Set terhadap Return Saham (Pada Saat Pelaporan Keuangan Perusahaan). Jurnal Keuangan dan Perbankan., 9(3), 369383.

Prastowo. (2014). Analisis Laporan Keuangan, Edisi Kedua. Yogyakarta: UUP AMP YKPN.

Purnami, K. D. A. (2016). Pengaruh Investment Opportunity Set, Total Asset Turn Over Dan Sales Growth Terhadap Kebijakan Dividen. E-Jurnal Manajemen Unud, 5(2), 1309-1337.

Puspitasari, N. L. P. (2016). Pengaruh Investment Opportunity Set (IOS) pada Kebijakan Dividen Tunai Dengan Umur Perusahaan Sebagai Variabel Pemoderasi. E-Jurnal Ekonomi dan Bisnis Universitas Udayana, 5(5), 1335-1358.

Reeve, M. (2014). Pengantar Akuntansi Adaptasi-Indonesia. Jakarta: Salemba Empat.

Riyanto, B. (2015). Dasar-Dasar Pembelanjaan Perusahaan. Yogyakarta: BPFE.

Ross, A. (2016). Pengantar Kuangan Perusahaan. Jakarta: Salemba Empat.

Rudianto. (2015). Pengantar Akuntansi Konsep \& Teknik Penyusunan Laporan Keuangan. Jakarta: Penerbit Erlangga.

Saputro, W. H. A. (2017). Pengaruh Profitabilitas, Free Cash Flow, Investment Opportunity Set Dan Leverage Terhadap Divident Payout Ratio. Widi Hastomo Adi Saputro (pp. 90-98).

Saragih, F. (2012). Pengaruh Laba Bersih Dan Arus Kas Operasi Terhadap Dividen Kas Pada Perusahaan Manufaktur Yang Terdaftar Di Bursa Efek Indonesia. Ekonomikawan: Jurnal Ekonomi \& Studi Pembangunan, 10(1-18).

Sari, R. F. (2018). Analisis Pengaruh Kepemilikan Manajerial, Kebijakan Utang, Profitabilitas, Ukuran Perusahaan, dan Kesempatan Investasi terhadap Kebijakan Dividen. Jurnal riset akuntansi Indonesia, 4(1), 1-13.

Sawir, A. (2018). Analisis Kinerja Keuangan dan Perencanaan Keuangan Perusahaan. Jakarta: PT. Gramedia Pustaka Utama.

Sudana, I. M. (2015). Manajemen Keuangan Perusahaan. Edisi Kedua. Jakarta: Erlangga.

Sugiyono. (2015). Metode Penelitian Kuantitatif Kualitatif Dan R\& D. Bandung: Alfabeta.

Sugiyono. (2016). Metode Penelitian Kuantitatif, Kualitatif, dan R\&D. Bandung: Alfabeta.

Sumarni, I. (2014). Pengaruh Investment Opportunity Set Terhadap Kebijakan Dividen. Jurnal Wawasan Manajemen, 2(2), 201-211.

Sunarto, \& Budi, A. P. (2010). Pengaruh Leverage, Ukuran Perusahaan dan Pertumbuhan Perrusahaan terhadap Profitabilitas. Telaah Manajemen Marlie, 6(1), 86-103.

Suryabrata, S. (2015). Metodologi Penelitian. Jakarta: Raja Grafindo Persada.

Syakur, A. S. (2015). Intermediate Accounting. Jakarta: AV Publisher.

Topowijono. (2016). Pengaruh Profitabilitas dan Leverage Terhadap Harga Saham (Studi pada Perusahaan Konstruksi dan Bangunan yang Terdaftar di Bursa Efek Indonesia Periode 20112014). Jurnal Administrasi Bisnis, 35(2), 181-188.

Warren, C. S. (2015). Pengantar Akuntansi. Jakarta: Salemba Empat.

Wirawati, A. K. (2016). Pengaruh inflasi, nilai tukar rupiah, suku bunga SBI pada indeks harga saham gabungan di BEI. E-Jurnal Akuntansi, 3(2), 421-435. 


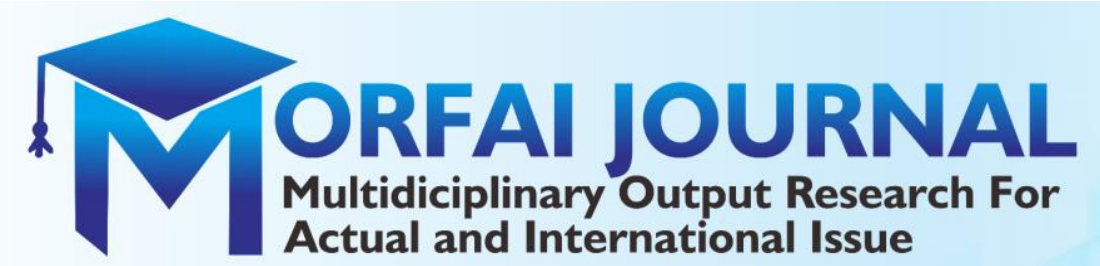

Yahya, D. K. (2017). Menumbuhkan dan Mempertahankan Kesetiaan Pelanggan. Jakarta: Husein Umar. 
Volume 1 No 2 (2021)

Determine Of Stock Price Volatility On Mining Companies On The Indonesia Stock Exchange DOI: $10.54443 /$ morfai.v1i2.71 